\title{
Reliability and validity of the Japanese version of the Feedback Environment Scale (FES-J) for workers
}

\author{
Hiroko MOMOTANI ${ }^{1 *}$ and Yasumasa OTSUKA ${ }^{2}$ \\ ${ }^{1}$ Workers' Mental Health Center, Yokohama Rosai Hospital, Japan Organization \\ of Occupational Health and Safety, Japan \\ ${ }^{2}$ Faculty of Human Sciences, University of Tsukuba, Japan
}

Received January 23, 2018 and accepted July 23, 2018

Published online in J-STAGE August 8, 2018

\begin{abstract}
The study objectives were to develop a Japanese-language version of the Feedback Environment Scale (FES) that is used, mainly in the West, as a multifaceted instrument to evaluate the workplace feedback environment, and to test its reliability and validity in the Japanese workplace. The FES (comprising Supervisor and Coworker FES) was translated into Japanese and reviewed through a back-translation process involving the original author to produce the FES-J. Data on 416 individuals working at Japanese companies obtained through internet research were used to investigate FES-J reliability (internal consistency) and validity (confirmatory factor analysis and correlation analysis). Cronbach's alpha coefficients were $\mathbf{0 . 6 8 - 0 . 9 2}$ for the Supervisor FES-J and 0.66-0.88 for the Coworker FES-J. The AIC scores and fit indices were $\chi^{2}(417)=1,396.655(p<0.001)$, $\mathrm{AIC}=1,618.655, \mathrm{CFI}=0.900$ and $\mathrm{RMSEA}=0.075$ for the Supervisor FES-J and $\chi^{2}(391)=1,859.302$ $(p<0.001), \mathrm{AIC}=\mathbf{2 , 0 6 9 . 3 0 2}, \mathrm{CFI}=\mathbf{0 . 8 3 9}$ and RMSEA $=0.095$ for the Coworker FES-J. Correlation analysis showed a positive relationship between both FES-J scales and feedback-seeking behavior, LMX/TMX, job satisfaction, and work engagement, and a negative relationship with irritability, fatigue, anxiety, and depression. This study showed a certain level of reliability and validity for the FES-J, suggesting that this is an appropriate scale for evaluating the feedback environment in Japanese workplaces.
\end{abstract}

Key words: Feedback environment, Scale development, Reliability, Validity, Japanese workers

\section{Introduction}

Workplace feedback is one category of information available to individuals at work. Feedback includes evaluation of appropriate actions to achieve one's goals and evaluation of how well such actions are being performed $^{1-3)}$. Feedback was originally provided to modify

*To whom correspondence should be addressed.

E-mail: hmomotani@nifty.com

(C)2019 National Institute of Occupational Safety and Health behavior in order to help employees maintain workrelated actions to achieve the required goals ${ }^{4-6}$. Feedback is generally linked to employee training, development, motivation, work performance, and other work-related outcomes; thus, it is a useful and important resource for the individual and the organization $3,7,8$.

According to Steelman et al..$^{9}$, the concept of the workplace feedback environment refers to "the contextual aspects of day-to-day supervisor-subordinate and coworker-coworker feedback processes rather than to the formal performance appraisal feedback session" (p166). 
The feedback process is key if feedback is to function effectively and it is assumed that feedback is more effective when given in a feedback environment that is supportive to feedback processes ${ }^{10)}$. Therefore, a workplace can be described as having a supportive feedback environment if employees receive feedback on a day-to-day basis from supervisors and coworkers, actively seek feedback from supervisors and coworkers, and can apply the feedback given $^{9,11)}$.

Steelman et al. ${ }^{9)}$ developed the Feedback Environment Scale (FES) to evaluate the degree of support for feedback processes in the workplace. The FES is a multifaceted instrument derived from the current literature that comprises seven facets that can be differentiated from each other but are mutually interrelated ${ }^{9}$. The feedback sources for the FES are the supervisors and coworkers who create the feedback environment of employees in the workplace. When using the Supervisor FES and Coworker FES, the supervisor feedback environment and the coworker feedback environment are measured separately by focusing on the employee's perceptions of seven facets: (1) source credibility-source expertise, trustworthiness and competency; (2) feedback quality-consistency and usefulness of the feedback; (3) feedback deliveryhow considerate and tactful the feedback source is at the time of delivery; (4) favorable feedback - frequency of warranted favorable feedback (positive feedback such as praise or success feedback which accurately reflects actual good performance on the job); (5) unfavorable feedbackfrequency of warranted unfavorable feedback (negative feedback such as criticism which accurately reflects actual performance on the job that is below expectations and is specific and behavioral, not centering on a critique of the employee as an individual); (6) source availabilitythe ease with which feedback is obtained from feedback sources; and (7) promotes feedback seeking - the extent to which feedback seeking is promoted and encouraged by feedback sources ${ }^{9}$.

Both the Supervisor and Coworker FES have adequate reliability and validity ${ }^{9}$. For validity, Steelman et al. ${ }^{9)}$ confirmed that the seven facets of the Supervisor and Coworker FES for employees at two companies in the US were consistent with a priori predictions in that they showed a positive correlation for feedback-seeking behavior and that the seven facets of the Supervisor FES were also positively correlated with leader-member exchange (LMX).

Since the development of the FES, there has been a lot of research demonstrating the relationship between the feedback environment and work-related variables and psychological distress ${ }^{12-20)}$. Studies have shown the feedback environment is positively correlated with job

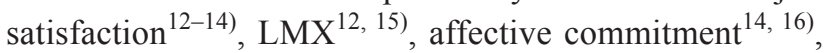
organizational commitment ${ }^{17)}$, person-organization fit $^{17)}$, role clarity ${ }^{18)}$, feedback-seeking behavior ${ }^{18)}$, work engagement ${ }^{19)}$, performance ${ }^{14,16,18)}$, and organizational citizenship behavior $(\mathrm{OCB})^{14-17)}$, and negatively correlated with depression ${ }^{13)}$, anxiety ${ }^{13)}$, burnout ${ }^{17}$, perceptions of politics ${ }^{14)}$, role ambiguity ${ }^{17)}$, role conflict ${ }^{17)}$, quantitative workload $^{20)}$, interpersonal conflict ${ }^{20)}$, turnover intentions $^{13)}$, and deviance ${ }^{20)}$. In summary, a more supportive feedback environment may ameliorate work-related variables and psychological distress.

This study investigated the relationship with the feedback environment for the following variables: feedbackseeking behavior, LMX, team-member exchange (TMX), job satisfaction, work engagement, and psychological distress.

Feedback-seeking behavior describes the behavior of proactively seeking out feedback ${ }^{3)}$. There are benefits from such behavior, such as a reduction in uncertainty and anxiety in the workplace, but also costs, such as concerns over being seen as incompetent or feeling personally threatened when receiving negative feedback, which can discourage employees from seeking feedback ${ }^{21)}$. However, a supportive feedback environment may make it easier for employees to seek out feedback. In the supervisor feedback environment, the supervisor encourages his/her subordinates to seek feedback, so we expect a positive correlation between the supervisor feedback environment and subordinates' feedback-seeking from their supervisor. Similarly, in the coworker feedback environment, the coworkers encourage other employees to seek feedback, so we expect a positive correlation between the coworker feedback environment and employees' feedback-seeking from coworkers.

LMX and TMX are both concepts based on social exchange relationships in the workplace ${ }^{22}$. LMX focuses on supervisor-subordinate relationships while TMX focuses on the relationships among team members (coworkers) ${ }^{23,24)}$. With a positive feedback environment from the supervisor, the supervisor has credibility and provides quality feedback to subordinates in a considerate and thoughtful manner ${ }^{9}$. The feedback behavior of this type of supervisor plays a role in subordinates achieving their goals, so subordinates may develop a liking for that supervisor and feel motivated to build a closer relationship with the supervisor. Experimental research to date has 
shown that the development of a liking between a supervisor and subordinate is an important predictive factor for $\mathrm{LMX}^{25,26)}$. Therefore, we expect a positive correlation between the supervisor feedback environment and LMX. Similarly, with a positive feedback environment from coworkers, feedback behavior by coworkers plays a role in employees achieving their goals, so employees may develop a liking for these coworkers and be motivated to build closer relationships with them. Moreover, a positive feedback environment from coworkers may promote daily interaction between coworkers in order for the team to achieve their goals together, and such frequent interaction is likely to foster sharing of resources and ideas, which are the primary elements in mutually beneficial TMX relationships ${ }^{24)}$. Therefore, we expect a positive correlation between the coworker feedback environment and TMX.

In a favorable feedback environment, employees receive constructive feedback throughout the year, so they understand how they are performing and how much their supervisors or coworkers are interested in them and their performance, and they are more likely to have favorable attitudes toward feedback, development, improvement of their job performance, and a favorable attitude toward their job (e.g., job satisfaction) overall ${ }^{9}$. Research has also shown that the way that feedback is communicated can affect that individual's attitude towards other members of the organization ${ }^{27)}$. This suggests that when an employee perceives a positive feedback environment, he/she may behave positively to other employees of the organization. Such positive behavior can facilitate interpersonal relationships and job execution in the workplace, thereby increasing job satisfaction. Therefore, we predict a positive correlation between both the supervisor and coworker feedback environment and job satisfaction.

Work engagement describes a fulfilling, positive workrelated state of mind ${ }^{28)}$. Previous research has shown that work engagement is increased through job resources (e.g., performance feedback), leading to good mental and physical health, a positive attitude to one's work and organization, and job performance ${ }^{28,29}$. These processes have been integrated into the Job Demands-Resources (JD-R) model ${ }^{28,29}$. According to the JD-R model, proper feedback may either play an intrinsic motivational role because it fosters employees' learning, thereby increasing job competence, or play an extrinsic motivational role because it is instrumental in achieving work goals. In either case, the outcome is positive and work engagement is likely to increase ${ }^{29)}$. In a positive feedback environment, employees receive proper feedback frequently from their supervisor and their coworkers ${ }^{9)}$ and this is useful for their development and job performance. Therefore, we expect a positive correlation between both the supervisor and coworker feedback environment and work engagement.

Previous studies have shown a negative correlation between the supervisor feedback environment and job stressors (role ambiguity ${ }^{17}$, role conflict ${ }^{17)}$, quantitative workload $^{20)}$, interpersonal conflict ${ }^{20)}$ ). A meta-analysis demonstrated a positive correlation between job stressors and psychological distress (e.g., anxiety, fatigue, depression $)^{30)}$. As such, a more supportive supervisor feedback environment may diminish job stressors, which in turn may reduce psychological distress. As well as the supportive supervisor feedback environment, the supportive coworker feedback environment may also reduce employees' job stressors; thus psychological distress may be alleviated through a reduction in job stressors. Therefore, we predict a negative correlation between both the supervisor and coworker feedback environment and psychological distress.

The FES has been translated into various languages, including German and Dutch, and is widely used in research, particularly in the West. Studies in the West have produced similar results of a positive relationship between the feedback environment and work-related variables (e.g., job satisfaction, LMX $)^{9,12-14,16,18)}$. Research is just starting in Asia with the FES being translated into Chinese. A study conducted in Taiwan ${ }^{15)}$ showed a positive correlation between the supervisor feedback environment and workrelated variables (LMX, OCB), similar to the results of research in the West. Another study in Taiwan ${ }^{17)}$ showed that the supervisor feedback environment was (a) negatively correlated with role stressors (role ambiguity and conflict) and burnout and (b) positively correlated with person-organization fit and organizational commitment. The research demonstrated that the supervisor feedback environment influenced employee OCB indirectly through these two processes ${ }^{17)}$. Yet another study in Taiwan ${ }^{20)}$ discovered that the supervisor feedback environment was negatively correlated to work-related stressors (quantitative workload and interpersonal conflict) and employee deviance, and moreover that these job stressors partially mediated the relationship between the feedback environment and employee deviance. These last two studies in Taiwan ${ }^{17,20)}$ suggest that a supportive supervisor feedback environment reduces job stressors. In Japan, the MHLW has reported that approx. $60 \%$ of workers feel high levels of work-related distress ${ }^{31}$. As well as improving workrelated variables in Japanese workplaces, we expect a supportive feedback environment to be beneficial by reducing 
job stressors and therefore ameliorating psychological distress. In short, the feedback environment could also be used as a valuable resource by organizations and individuals to improve job performance and promote good health in the Japanese workplace. To investigate the relationship between the feedback environment and various variables in Japanese workplaces, we need to apply the concept of the feedback environment and evaluate it with Japanese employees. Improvement in the workplace feedback environment is an area that can be controlled by the organization ${ }^{9)}$ and systematic improvement of the workplace feedback environment may ensure feedback functions effectively. Even though researchers are starting to investigate the workplace feedback environment, we have yet to find an instrument capable of appropriately evaluating the workplace feedback environment in Japan and that is of proven reliability and validity. The objectives of this study therefore were to develop a Japanese-language version of the FES (FES-J) to evaluate the workplace feedback environment and to test its reliability and validity in the Japanese workplace.

\section{Participants and Methods}

\section{Participants and data collection}

Internet-based research was conducted in June 2016. Participants in this study were drawn from a pool of people registered with an internet-survey company. Informed consent, which included assurances that personal information is protected and that data is anonymized, was obtained from all participants before they answered the questionnaire. Any identifying information, such as the participant's name and other identifiers that could lead to identification of a participant, had already been removed when we received the data from the internet-survey company. Inclusion criteria were: (1) male and female full-time employees (20-64 yr of age; in non-managerial positions, day duties), (2) working at Japanese companies with a direct supervisor and coworkers, and (3) working in an environment where they can receive feedback from their supervisor and coworkers on an almost daily basis. Participants registered at the internet-survey company and who fulfilled these criteria were invited to participate in this study via email from the internet-survey company. Data collection was finished when responses had been received from 515 individuals. An attentiveness check item (e.g., "This is an attentiveness check; please indicate 'strongly agree'.") derived from the HEXACO Personality Inventory-Revised (HEXACO-PI$\mathrm{R}) \mathrm{scale}^{32)}$ was included in the questionnaire of the study and individuals who did not follow directions and did not choose "strongly agree" were dropped from the study; 99 individuals were dropped. Consequently, analysis was conducted on the responses from 416 individuals who provided proper answers ( $80.8 \%$ effective response rate). The sample size for this research met the criteria of including at least 100 individuals for factor analysis and a minimum of 5-7 times the number of items in the FES-J (63 items in total $)^{33)}$. This study was approved by the Research Ethics Committee of the Faculty of Human Sciences, University of Tsukuba (No. TOU 28-13).

\section{Measurements}

Feedback environment: The original $\mathrm{FES}^{9)}$ comprises the Supervisor FES and the Coworker FES. Both FES are divided into seven subscales that reflect the seven facets of the feedback environment. The Supervisor FES and the Coworker FES consist of 32 items and 31 items, respectively: (1) source credibility (five items for both FES); (2) feedback quality (five items for both); (3) feedback delivery (five items for both); (4) favorable feedback (four items for both); (5) unfavorable feedback (four items for both); (6) source availability (five items for the Supervisor FES, four items for the Coworker FES); and (7) promotes feedback seeking (four items for both).

Items for the seven facets of the Supervisor and Coworker FES are parallel to each other. Example items are "My supervisor/coworkers are generally familiar with my performance on the job" in the source credibility facet and "My supervisor/coworkers give me useful feedback about my job performance" in the feedback quality facet. Items were scored on a seven-point Likert scale, ranging from 1 (strongly disagree) to 7 (strongly agree). For both the Supervisor and Coworker FES, a high score shows a positive (supportive) feedback environment.

We developed the FES-J based on the original FES from Steelman et al. ${ }^{9)}$ and in line with guidelines from the International Society for Pharmacoeconomics and Outcomes Research (ISPOR) ${ }^{34)}$. To ensure cross-linguistic equivalence, we translated all scale items into Japanese and then translated them back into English by means of two bilingual (English-Japanese) professional translators ${ }^{35)}$. The primary author and one researcher, who are both psychology specialists, independently produced forward translations of the original $\mathrm{FES}^{9)}$ from English into Japanese. The primary author then compared these two translations, made revisions to ensure the original English content was appropriately reflected in the Japanese, and combined them into a single version. Opinions were then 
sought from a number of psychologists and revisions were made to ensure usage of the most appropriate Japanese expressions. A native English-speaking translator then produced a back translation of this version from Japanese into English. The original author of the English-language FES then reviewed this back translation to ensure the translated scale included the same concepts and meanings as the original version. The primary author then confirmed that the corrections made were accurate and improved the translation, resulting in the final FES-J (Supervisor and Coworker FES-J) (see Appendix). In this study, we used both the Supervisor FES-J and Coworker FES-J.

Feedback-seeking behavior: The research used a feedback-seeking behavior scale ${ }^{36}$ developed with reference to work by Ashford ${ }^{37)}$ and Morrison ${ }^{38)}$. By replacing the "supervisor or coworker" target of the feedback-seeking behavior with "supervisor" and "coworker", we developed a supervisor scale $(\alpha=0.89)$ and a coworker scale $(\alpha=0.92)$ (four items for both; e.g., "I often ask for feedback from my supervisor/coworkers on the execution of my work"). Items were scored on a five-point Likert scale, ranging from 1 (completely disagree) to 5 (completely agree). With this scale, a high score shows frequent feedback-seeking behavior.

LMX and TMX: For LMX, the research used a vertical exchange relationship scale $\left.{ }^{39}\right)(\alpha=0.92)$ (nine items; e.g., "My supervisor fully understands my problems and aspirations in my work"). For TMX, the research used a horizontal exchange relationship scale ${ }^{39)}(\alpha=0.90)$, replacing "women around me" with "coworkers" (seven items; e.g., "My coworkers and I fully understand and agree with the problems and aspirations that my coworkers and I have in our work"). Items were scored on a five-point Likert scale, ranging from 1 (completely disagree) to 5 (completely agree). With this scale, a high score shows high quality relationships.

Job satisfaction: The research used a job satisfaction scale ${ }^{40)}$ developed based on the job satisfaction scale from McLean ${ }^{41)}$. The scale consists of one general job satisfaction scale $(\alpha=0.91)$ (four items; e.g., "I am satisfied with my current work overall") and three scales for job satisfaction that measure an individual's sense of satisfaction regarding the workplace environment, including (1) satisfaction with job-related career $(\alpha=0.86)$ (four items; e.g., "My current salary is suitable for my work responsibilities and content"), (2) satisfaction with employee relations $(\alpha=0.77)$ (three items; e.g., "I am satisfied with how my supervisor handles his/her subordinates and his/ her people management skills" and "I am satisfied with my coworkers who are cooperative"), and (3) satisfaction with usage of one's own abilities $(\alpha=0.80)$ (three items; e.g., "I am satisfied with my current job because I can use my skills and capabilities"). Items were scored on a fivepoint Likert scale, ranging from 1 (no) to 5 (yes). With this scale, a high score shows high job satisfaction.

Work engagement: The Japanese short version of the Utrecht Work Engagement Scale (UWES-J) was used ${ }^{42,43)}$. This scale comprises (1) vigor $(\alpha=0.88)$ (three items; e.g., "At my work, I feel bursting with energy"), (2) dedication $(\alpha=0.84)$ (three items; e.g., "I am enthusiastic about my job"), and (3) absorption ( $\alpha=0.88)$ (three items; e.g., "I feel happy when I am working intensely"). Items were scored on a seven-point Likert scale, ranging from 0 (never) to 6 (always). A high score shows high work engagement.

Psychological distress: We used the Brief Job Stress Questionnaire (BJSQ) ${ }^{44)}$ subscales on psychological distress, namely (1) irritability ( $\alpha=0.93$ ) (three items; e.g., "I have felt irritable"), (2) fatigue $(\alpha=0.90)$ (three items; e.g., "I have felt extremely tired"), (3) anxiety ( $\alpha=0.82$ ) (three items; e.g., "I have felt worried or insecure"), and (4) depression $(\alpha=0.92)$ (six items; e.g., "I have been depressed"). Items were scored on a four-point Likert scale, ranging from 1 (almost never) to 4 (almost always). A low score shows a good psychological state.

Demographics: Study participants included in the analysis were asked about their sex, age, organizational tenure, job tenure, corporate size, department size, job type, and industry, as well as about their immediate supervisor's sex and age, whether their supervisor was in a managerial or non-managerial role, and how long they had worked under their direct supervisor.

\section{Analyses}

\section{Internal consistency reliability}

Reliability was investigated using Cronbach's alpha coefficient that is an indicator of internal consistency.

\section{Construct validity}

The FES-J was subjected to confirmatory factor analysis (CFA), as the original FES had been ${ }^{9)}$, to investigate whether the seven-factor model was a good fit compared with the one-factor model. We calculated the chi-square test of model fit, Akaike's information criterion (AIC), the comparative fit index (CFI) and the root mean square error of approximation (RMSEA). We defined an appropriate range as CFI $\geq 0.90$ and RMSEA $<0.08^{45}$. We then calculated Pearson's correlation coefficients for work-related 
variables and psychological distress versus the Supervisor and Coworker FES-J. IBM SPSS Statistics version 24 and Amos version 24 (IBM Corp., NY, USA) were used for the statistical analysis.

\section{Results}

Characteristics of study participants and their supervisors

Table 1 shows the demographic profiles of the participants. The 416 supervisors of the participants (329 males, 87 females) had an average age of $47.9 \pm 9.2 \mathrm{yr}$ (age range: $25-74 \mathrm{yr}$ ) and $83.2 \%$ were in managerial positions. The participants had worked under their immediate supervisor for a median duration of 36 months (duration range: 6-376 months).

\section{Internal consistency reliability}

Table 2 shows descriptive statistics and Cronbach's alpha coefficients for the FES-J. The alpha coefficient was slightly below 0.70 for promotes feedback seeking, but was above 0.70 for the six other subscales of source credibility, feedback quality, feedback delivery, favorable feedback, unfavorable feedback, and source availability for both the Supervisor and Coworker FES-J. Overall alpha coefficients for both FES-J were 0.96 .

\section{Construct validity}

The Supervisor FES-J was developed as a 32-item seven-factor model and the Coworker FES-J a 31-item seven-factor model, just like the original FES, and these seven-factor models were tested using CFA. The original FES has been used as a single concept in multiple studies $^{12,14-18,20)}$, so we performed CFA for one-factor models as well and compared the seven-factor models of the Supervisor and Coworker FES-J with each of the one-factor models. Table 3 indicates that both the Supervisor and Coworker FES-J seven-factor models (Model 2) provided more appropriate scores of AIC and fit for the data than the one-factor models (Model 1). The score of AIC and fit indices for the seven-factor model (Model 2) of the Supervisor FES-J were set at $\chi^{2}(417)=1,396.655(p<0.001)$, $\mathrm{AIC}=1,618.655, \mathrm{CFI}=0.900$ and $\mathrm{RMSEA}=0.075$, and the results showed a generally appropriate fit. In contrast, the score of AIC and fit indices for the seven-factor model (Model 2) of the Coworker FES-J were $\chi^{2}(391)=1,859.302$ $(p<0.001), \mathrm{AIC}=2,069.302, \mathrm{CFI}=0.839$ and $\mathrm{RM}-$ $\mathrm{SEA}=0.095$, suggesting insufficient fit. However, RMSEA did not exceed 0.10 that is considered the limit of the acceptable range ${ }^{46)}$, so we did not abandon this model.
Table 1. Characteristics of the study participants $(n=416)$

\begin{tabular}{|c|c|c|}
\hline & $\mathrm{n}$ & $(\%)$ \\
\hline \multicolumn{3}{|l|}{ Sex } \\
\hline Male & 208 & $(50.0)$ \\
\hline Female & 208 & $(50.0)$ \\
\hline \multicolumn{3}{|l|}{ Age } \\
\hline Less than $30 \mathrm{yr}$ & 81 & $(19.5)$ \\
\hline 30 to $39 \mathrm{yr}$ & 148 & $(35.6)$ \\
\hline 40 to $49 \mathrm{yr}$ & 122 & $(29.3)$ \\
\hline 50 to $59 \mathrm{yr}$ & 55 & $(13.2)$ \\
\hline $60 \mathrm{yr}$ or more & 10 & $(2.4)$ \\
\hline \multicolumn{3}{|l|}{ Organizational tenure } \\
\hline Less than $3 \mathrm{yr}$ & 78 & $(18.8)$ \\
\hline 3 to $<10 \mathrm{yr}$ & 170 & $(40.9)$ \\
\hline 10 to $<20 \mathrm{yr}$ & 105 & $(25.2)$ \\
\hline $20 \mathrm{yr}$ or more & 63 & $(15.1)$ \\
\hline \multicolumn{3}{|l|}{ Job tenure } \\
\hline Less than $3 \mathrm{yr}$ & 131 & $(31.5)$ \\
\hline 3 to $<10 \mathrm{yr}$ & 200 & $(48.1)$ \\
\hline 10 to $<20 \mathrm{yr}$ & 65 & (15.6) \\
\hline $20 \mathrm{yr}$ or more & 20 & $(4.8)$ \\
\hline \multicolumn{3}{|l|}{ Corporate size } \\
\hline Less than 50 employees & 167 & $(40.1)$ \\
\hline 50 to 299 employees & 114 & $(27.4)$ \\
\hline 300 to 999 employees & 83 & $(20.0)$ \\
\hline 1,000 employees or more & 52 & $(12.5)$ \\
\hline \multicolumn{3}{|l|}{ Department size } \\
\hline Less than 10 employees & 191 & $(45.9)$ \\
\hline 10 to 29 employees & 133 & $(32.0)$ \\
\hline 30 to 49 employees & 39 & $(9.4)$ \\
\hline 50 employees or more & 53 & $(12.7)$ \\
\hline \multicolumn{3}{|l|}{ Job type } \\
\hline Office work & 156 & $(37.5)$ \\
\hline Profession, Technical research & 101 & $(24.3)$ \\
\hline Service & 59 & $(14.2)$ \\
\hline Production & 37 & $(8.9)$ \\
\hline Sales & 35 & $(8.4)$ \\
\hline Others & 28 & $(6.7)$ \\
\hline \multicolumn{3}{|l|}{ Industry } \\
\hline Manufacturing & 106 & $(25.5)$ \\
\hline Services & 72 & $(17.3)$ \\
\hline Medical, health care and welfare & 66 & $(15.9)$ \\
\hline Information and communications & 39 & $(9.4)$ \\
\hline Wholesale and retail trade & 26 & $(6.3)$ \\
\hline Construction & 24 & $(5.8)$ \\
\hline Transport and postal activities & 21 & $(5.0)$ \\
\hline Eating and drinking services & 19 & $(4.6)$ \\
\hline Finance and Insurance & 18 & $(4.3)$ \\
\hline Electricity, gas, and water & 9 & $(2.2)$ \\
\hline Education and allied industries & 9 & $(2.2)$ \\
\hline Others & 7 & $(1.7)$ \\
\hline
\end{tabular}

All participants are full-time employees working in the daytime with nonmanagerial positions. 
Table 2. Descriptive statistics and reliability coefficients for FES-J $(n=416)$

\begin{tabular}{lrrrrr}
\hline \multicolumn{1}{c}{ FES-J by source } & No. of items & Range & Mean & SD & $\alpha$ \\
\hline Supervisor FES-J & & & & & \\
Overall & 32 & $1-7$ & 4.36 & 0.93 & 0.96 \\
Source credibility & 5 & $1-7$ & 4.41 & 1.11 & 0.87 \\
Feedback quality & 5 & $1-7$ & 4.41 & 1.22 & 0.92 \\
Feedback delivery & 5 & $1-7$ & 4.21 & 1.06 & 0.86 \\
Favorable feedback & 4 & $1-7$ & 4.16 & 1.11 & 0.83 \\
Unfavorable feedback & 4 & $1-7$ & 4.26 & 1.06 & 0.82 \\
Source availability & 5 & $1-7$ & 4.62 & 1.05 & 0.77 \\
Promotes feedback seeking & 4 & $1-7$ & 4.43 & 0.92 & 0.68 \\
Coworker FES-J & & & & & \\
Overall & 31 & $1-7$ & 4.33 & 0.80 & 0.96 \\
Source credibility & 5 & $1-7$ & 4.31 & 0.93 & 0.83 \\
Feedback quality & 5 & $1-7$ & 4.37 & 0.98 & 0.88 \\
Feedback delivery & 5 & $1-7$ & 4.23 & 0.84 & 0.76 \\
Favorable feedback & 4 & $1-7$ & 4.18 & 0.96 & 0.78 \\
Unfavorable feedback & 4 & $1-7$ & 4.13 & 0.98 & 0.83 \\
Source availability & 4 & $1-7$ & 4.77 & 1.05 & 0.78 \\
Promotes feedback seeking & 4 & $1-7$ & 4.38 & 0.83 & 0.66 \\
\hline
\end{tabular}

FES-J: Japanese version of the Feedback Environment Scale; SD: standard deviation; $\alpha$ : Cronbach's alpha coefficient.

Table 3. AIC scores and fit indices of confirmatory factor analysis models $(n=416)$

\begin{tabular}{ccccccc}
\hline Model & $\chi^{2}$ & $d f$ & $p$ & AIC & CFI & RMSEA \\
\hline Supervisor FES-J & & & & & & \\
$\quad$ Model 1 (One-factor model) & $1,736.357$ & 438 & $<0.001$ & $1,916.357$ & 0.868 & 0.085 \\
$\quad$ Model 2 (Seven-factor model) & $1,396.655$ & 417 & $<0.001$ & $1,618.655$ & 0.900 & 0.075 \\
Coworker FES-J & & & & & & \\
$\quad$ Model 1 (One-factor model) & $2,061.518$ & 412 & $<0.001$ & $2,229.518$ & 0.819 & 0.098 \\
Model 2 (Seven-factor model) & $1,859.302$ & 391 & $<0.001$ & $2,069.302$ & 0.839 & 0.095 \\
\hline
\end{tabular}

FES-J: Japanese version of the Feedback Environment Scale; AIC: Akaike's information criterion; CFI: comparative fit index; RMSEA: root mean square error of approximation.

Table 4 shows the correlation coefficients for the FES$\mathrm{J}$ with work-related variables and psychological distress. The results showed that the supervisor feedback environment had significantly positive correlations with feedbackseeking behavior from individuals' supervisors, LMX, job satisfaction, and work engagement. Similarly, the results showed that the coworker feedback environment had significantly positive correlations with feedback-seeking behavior from individuals' coworkers, TMX, job satisfaction, and work engagement. For psychological distress, overall there was a significant negative correlation with the Supervisor FES-J, but a significant negative correlation with the Coworker FES-J for only two of the subscales, namely irritability and depression. No significant correlations were observed with fatigue and anxiety.

\section{Discussion}

We developed a Japanese version of the FES (FES-J) used to evaluate the workplace feedback environment and confirmed that the FES-J has a certain level of reliability and validity when used with employees at Japanese companies.

The results showed generally good reliability for the FES-J. The alpha coefficients of the Supervisor and Coworker FES-J were high enough for six of the subscales and reached the minimum level required for the remaining subscale of promotes feedback seeking, although the coefficients were slightly low. For promotes feedback seeking, the FES-J was less internally consistent than the original FES $^{9)}$, with supervisor source alpha coefficients of FES- 


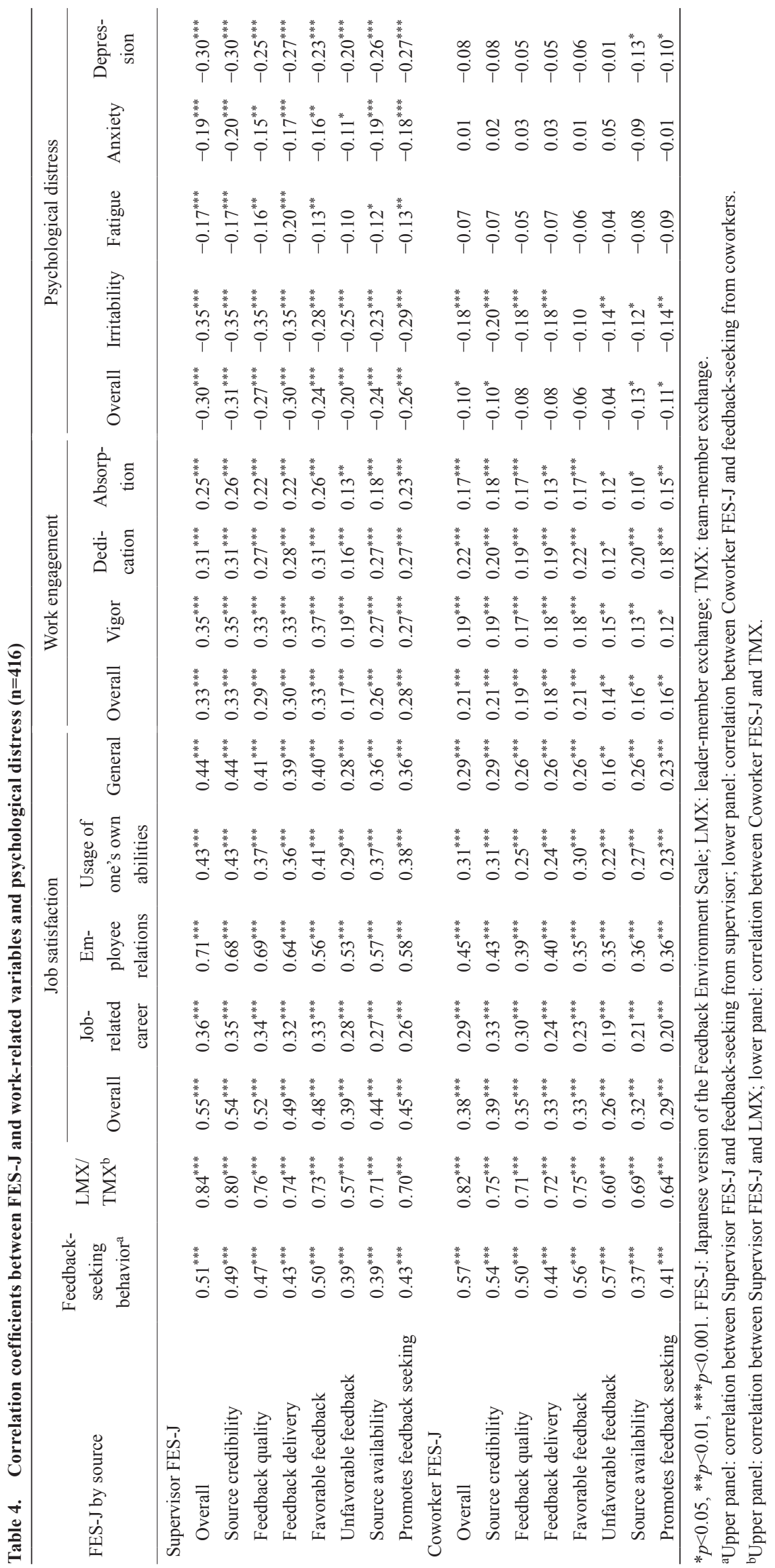


$\mathrm{J}(\alpha=0.68)$ and FES $(\alpha=0.84)$, and coworker source alpha coefficients of FES-J $(\alpha=0.66)$ and FES $(\alpha=0.85)$. The supervisor FES translated into Chinese had an alpha coefficient of $0.65^{20)}$, which is identical with that for the FES-J. This suggests that the different results in the Western and Asian research may be partly due to cultural differences. For example, it has been reported that American workers seek feedback more frequently than workers from Hong Kong and that this may be related to cultural differences in self-assertion and power distance ${ }^{47)}$. Further research should investigate the determinants of feedback seeking with Japanese employees.

CFA showed that the seven-factor model was a better fit than the one-factor model for both the Supervisor and Coworker FES-J. Moreover, the seven-factor model provided a good fit for the Supervisor FES-J, but the fit for the Coworker FES-J was suboptimal. Because the RMSEA values were not at a level suggesting the model be abandoned, we conclude that the FES-J has a certain validity as a seven-factor model like the original FES. One advantage is that it will be easier to compare the results from research in Japan with that conducted in other countries if the FES$\mathrm{J}$ has the same factorial structure as the original FES.

The supervisor feedback environment was a better fit than the coworker feedback environment and Steelman et al. ${ }^{9)}$ suggested two potential explanations for this difference: (1) the group of individuals an employee calls "coworkers" may be open to some interpretation and employees may be able to more easily identify their supervisor than their coworkers, which might result in more consistent results for the supervisor results, and (2) the work environment tends to be dynamic, with coworkers coming and going and work teams established as shortterm entities based on business need, but a worker's relationship with their supervisor tends to be more stable. We think these explanations apply to the Japanese workplace as well. Another explanation may be that the various different coworkers create different feedback environments, so responses to the FES-J for coworker feedback environments tend to be more complex and unstable compared with responses relating to the feedback environment produced by a single supervisor. More research is needed to further delineate the feedback environment in well-defined work teams ${ }^{9)}$ and we need to develop more sophisticated response methods.

We then confirmed the relationship between the FES-J and the work-related variables and psychological distress. For the Supervisor FES-J, we demonstrated a positive correlation with the work-related variables of a subordinate's feedback-seeking behavior from the supervisor, LMX, job satisfaction, and work engagement, and a negative correlation with psychological distress. Therefore, the results of the CFA and the correlations confirm the construct validity for the Supervisor FES-J. For the Coworker FES-J as well, the research demonstrated a positive correlation with the work-related variables of an employee's feedback-seeking behavior from coworkers, TMX, job satisfaction, and work engagement, and a negative correlation for some of the psychological distress facets. Therefore, the results of the CFA and the correlations suggest that the construct in the Coworker FES-J is mostly but not completely valid.

The results suggested a tendency towards a negative correlation between the supervisor and coworker feedback environments and psychological distress. However, contrary to our expectations for the coworker feedback environment, this correlation only applied to some aspects of psychological distress (e.g., irritability) and the study did not demonstrate the expected level of correlation. This may be because supervisors have greater authority and influence and control access to the required resources compared with coworkers ${ }^{48,49}$. For example, workplace stressors such as uncertainty, which is a combination of role ambiguity and conflict, are related to depression, psychosomatic complaints, irritation, and worrying ${ }^{50)}$. Psychological distress can be ameliorated by a supervisor providing appropriate feedback and reducing uncertainty. In practice, the supervisor feedback environment has been shown to have a negative correlation with role ambiguity and conflict ${ }^{17)}$.

In contrast, the coworker feedback environment was negatively correlated with some, but not all, aspects of psychological distress. Some recently published research may help to explain these results. Gabriel et al. ${ }^{51)}$ showed that the relationship between the supervisor feedback environment and three aspects of subordinate psychological empowerment changed according to the subordinate's feedback orientation. There was a positive correlation between the feedback environment and the meaning, competence, and self-determination aspects of empowerment for subordinates with a higher feedback orientation. However, for subordinates with a lower feedback orientation, there was a weakly positive relationship with meaning, but a negative relationship with competence and self-determination. Although a supportive feedback environment is generally thought to be beneficial based on the conclusions from various studies performed before, some results suggest that a supportive feedback environment may not necessarily be beneficial for all employees ${ }^{51)}$. 
Feedback orientation describes an individual's receptivity and processing of feedback and the likelihood that they will act on the feedback, and can vary widely between employees ${ }^{11,18,52)}$. Therefore, even if the feedback environment is beneficial for individuals with a favorable orientation to feedback, it may not be very beneficial for individuals who do not necessarily want to receive or use feedback, particularly from coworkers. However, feedback orientation was not measured in this study, so further research is needed to confirm our assumption.

The results from our research also showed a positive correlation between the supervisor feedback environment and subordinate feedback-seeking from supervisors, as well as a positive correlation between the coworker feedback environment and employee feedback-seeking from coworkers. This was in line with our expectations and similar to research findings in the US ${ }^{9}$. This also supports the findings from previous research that suggested a connection between a supportive feedback environment that encourages feedback seeking and employee's feedbackseeking behavior ${ }^{18,21,53)}$. We also observed a positive correlation between one FES-J facet: unfavorable feedback and feedback-seeking behavior from individuals' supervisors in the supervisor feedback environment and a positive correlation between the unfavorable feedback facet and feedback-seeking behavior from individuals' coworkers in the coworker feedback environment, as also seen in the US research results ${ }^{9}$. Negative feedback is more likely to be rejected than positive feedback ${ }^{7}{ }^{54}$. However, even if the feedback is unfavorable, the research shows that subordinates are motivated to use this feedback to improve performance as long as the feedback is perceived to be good quality and is communicated by credible supervisors in a considerate manner ${ }^{55)}$. The research in both the US and Japan suggests that in workplaces with supportive feedback environments, employees can be expected to actively seek unfavorable feedback from supervisors and coworkers in order to improve their performance.

As expected, we demonstrated that the supervisor feedback environment was positively correlated with LMX, as in previous research ${ }^{9,12,15)}$, and the coworker feedback environment was positively correlated with TMX. As noted above, LMX and TMX are both concepts based on social exchange relationships in the workplace ${ }^{22)}$. When supervisors and coworkers create quality LMX and TMX in the workplace, there is value to the relationship with the other party that can create reciprocity in terms of a positive response to work expectations ${ }^{25}$ 56). In a supportive feedback environment, useful feedback on job execution is readily given by supervisors and coworkers; employees receiving good feedback may use this feedback to improve performance and meet the expectations of the other party. In this supportive feedback environment, feedback is used in an interactive way between supervisors and subordinates and between coworkers - the parties involved build high quality relationships through this process. Therefore, a more supportive supervisor and coworker feedback environment can be correlated with higher quality LMX and TMX, respectively.

Our research showed a positive correlation between both the supervisor and coworker feedback environment and job satisfaction as we had expected. This finding for the supervisor feedback environment was also seen in previous research $^{12-14)}$. The attitude of the supervisor when communicating supportive and constructive feedback is related to positive outcomes, such as subordinate satisfaction, perception of fairness, and motivation to improve work performance ${ }^{57)}$. In a supportive feedback environment, feedback is communicated in a thoughtful way, so employees are likely to respond positively and think that they are being managed with care ${ }^{58)}$. Employees emphasize interpersonal relationships as a result and can develop a more positive attitude (e.g., job satisfaction) towards their organization and job role such that they respond to their supervisor or coworker expectations. Therefore, a more supportive supervisor and coworker feedback environment can be correlated with a high level of employee job satisfaction.

Other expected findings from our research were the positive correlation between the supervisor feedback environment and work engagement, as seen in previous research ${ }^{19)}$, and the positive correlation between the coworker feedback environment and work engagement as well. Feedback is positioned as a job resource in the JD-R model ${ }^{28,29)}$. According to experimental studies using the JD-R model, feedback improves work engagement ${ }^{28,59-61)}$. Because feedback is a job resource, a feedback environment that functions to make feedback more effective should also be considered a job resource. Therefore, more supportive supervisor and coworker feedback environments can improve employee work engagement.

This research confirmed that the results from previous studies in the West and in Taiwan, which showed a beneficial relationship between the feedback environment and work-related factors and psychological distress $9,12-15,18,19)$, are applicable to Japanese organizations. The replication of these results suggests that the FES-J is an appropriate scale for measuring the feedback environment. We think 
this study has contributed to advances in this field, as it has confirmed that this relationship applies in Asia (Japan).

In terms of the limitations of this research, firstly because this study was a cross-sectional study and all data on samples were obtained at a single point in time, we cannot infer that the reliability results are repeatable. The FES-J reliability was evaluated by calculating Cronbach's alpha coefficient, but not evaluated by a test-retest method as seen with the original FES. This is an area for further research in the future. Secondly, the Coworker FES-J did not have sufficient validity compared with the Supervisor FES-J. In this study, we developed the FES-J based on the factorial structure of the original FES from Steelman et $a l^{9)}$. Further studies should re-examine goodness of fit for the Coworker FES-J with other Japanese samples. However, we think that this study provided important findings on the coworker feedback environment, given the little research into the coworker feedback environment thus far ${ }^{9}$ 14, 18) , as most attention has been focused on the role of the supervisor feedback environment, regardless of whether coworkers play an important role as sources of informal feedback on a day-to-day basis ${ }^{62)}$. Thirdly, because our data were collected from individuals registered with an internet-survey company, we cannot guarantee whether our results apply to Japanese workers in general. In order to draw general conclusions from this research, further studies are needed with more Japanese employees. Fourthly, the study used variables obtained from the same respondents on the same questionnaires, which may have resulted in common method bias ${ }^{63)}$. Future research should include objective data, such as the addition of variables on the actual individual's attitude and behavior and responses from the supervisor and other coworkers.

\section{Conclusion}

The study showed a certain level of reliability and validity for both the Supervisor and Coworker FES-J, suggesting that this scale is appropriate for evaluating the feedback environment in Japanese workplaces.

\section{Acknowledgements}

The authors would like to thank Dr. Lisa A. Steelman of Florida Institute of Technology for the review of the FES back-translation and her valuable suggestions and comments to improve the quality of the translation. The authors would also like to express their thanks to Rie Kusaba, Jenny Harry, Seiki Nakamaru, Takatsugu Nishimura,
Kayoko Yoshimura, Atsuyo Akiba, and Chikako Eto for their professional support.

\section{References}

1) Greller MM, Herold DM (1975) Sources of feedback: a preliminary investigation. Organ Behav Hum Perform 13, 244-56. [CrossRef]

2) Herold DM, Greller MM (1977) Feedback: the definition of a construct. Acad Manage J 20, 142-7.

3) Ashford SJ, Cummings LL (1983) Feedback as an individual resource: personal strategies of creating information. Organ Behav Hum Perform 32, 370-98. [CrossRef]

4) Hyland ME (1988) Motivational control theory: an integrative framework. J Pers Soc Psychol 55, 642-51. [CrossRef]

5) Taylor MS, Fisher CD, Ilgen DR (1984) Individual's reactions to performance feedback in organizations: control theory perspective. In: Research in personnel and human resource management, Rowland KM and Ferris GR (Eds.), 81-124, JAI press, Greenwich.

6) Larson JR (1989) The dynamic interplay between employees' feedback-seeking strategies and supervisors' delivery of performance feedback. Acad Manage Rev 14, 408-22. [CrossRef]

7) Ilgen DR, Fisher CD, Taylor MS (1979) Consequences of individual feedback on behavior in organizations. J Appl Psychol 64, 349-71. [CrossRef]

8) Kluger AN, DeNisi A (1996) The effects of feedback interventions on performance: a historical review, a metaanalysis, and a preliminary feedback intervention theory. Psychol Bull 119, 254-84. [CrossRef]

9) Steelman LA, Levy PE, Snell AF (2004) The feedback environment scale: construct definition, measurement, and validation. Educ Psychol Meas 64, 165-84. [CrossRef]

10) Levy PE, Williams JR (2004) The social context of performance appraisal: a review and framework for the future. J Manage 30, 881-905.

11) London M, Smither JW (2002) Feedback orientation, feedback culture, and the longitudinal performance management process. Hum Resour Manage Rev 12, 81-100. [CrossRef]

12) Anseel F, Lievens F (2007) The long-term impact of the feedback environment on job satisfaction: a field study in a Belgian context. Appl Psychol 56, 254-66. [CrossRef]

13) Sparr JL, Sonnentag S (2008) Feedback environment and well-being at work: the mediating role of personal control and feelings of helplessness. Eur J Work Organ Psychol 17, 388-412. [CrossRef]

14) Rosen CC, Levy PE, Hall RJ (2006) Placing perceptions of politics in the context of the feedback environment, employee attitudes, and job performance. J Appl Psychol 91, 211-20. [Medline] [CrossRef] 
15) Peng JC, Lin J (2016) Linking supervisor feedback environment to contextual performances: the mediating effect of leader-member exchange. Leadersh Organ Dev J 37, 802-20. [CrossRef]

16) Norris-Watts C, Levy PE (2004) The mediating role of affective commitment in the relation of the feedback environment to work outcomes. J Vocat Behav 65, 351-65. [CrossRef]

17) Peng JC, Chiu SF (2010) An integrative model linking feedback environment and organizational citizenship behavior. J Soc Psychol 150, 582-607. [Medline] [CrossRef]

18) Whitaker BG, Dahling JJ, Levy P (2007) The development of a feedback environment and role clarity model of job performance. J Manage 33, 570-91.

19) Young SF, Steelman LA (2017) Marrying personality and job resources and their effect on engagement via critical psychological states. Int J Hum Resour Manage 28, 797-824. [CrossRef]

20) Peng JC, Tseng MM, Lee YL (2011) Relationships among supervisor feedback environment, work-related stressors, and employee deviance. J Nurs Res 19, 13-24. [Medline] [CrossRef]

21) Ashford SJ, Northcraft GB (1992) Conveying more (or less) than we realize: the role of impression-management in feedback-seeking. Organ Behav Hum Decis Process 53, 310-34. [CrossRef]

22) Kamdar D, Van Dyne L (2007) The joint effects of personality and workplace social exchange relationships in predicting task performance and citizenship performance. J Appl Psychol 92, 1286-98. [Medline] [CrossRef]

23) Graen G, Cashman JF, Ginsburg S, Schiemann W (1977) Effects of linking-pin quality on the quality of working life of lower participants. Adm Sci Q 22, 491-504. [CrossRef]

24) Seers A (1989) Team-member exchange quality: a new construct for role-making research. Organ Behav Hum Decis Process 43, 118-35. [CrossRef]

25) Liden RC, Wayne SJ, Stilwell D (1993) A longitudinal study on the early development of leader-member exchanges. J Appl Psychol 78, 662-74. [CrossRef]

26) Engle EM, Lord RG (1997) Implicit theories, selfschemas, and leader-member exchange. Acad Manage J 40, 988-1010.

27) Becker TE, Klimoski RJ (1989) A field study of the relationship between the organizational feedback environment and performance. Person Psychol 42, 343-58. [CrossRef]

28) Schaufeli WB, Bakker AB (2004) Job demands, job resources, and their relationship with burnout and engagement: a multi-sample study. J Organ Behav 25, 293-315. [CrossRef]

29) Bakker AB, Demerouti E (2007) The job demandsresources model: state of the art. J Manag Psychol 22, 309-28. [CrossRef]

30) LePine JA, Podsakoff NP, LePine MA (2005) A meta- analytic test of the challenge stressor-hindrance stressor framework: an explanation for inconsistent relationships among stressors and performance. Acad Manage J 48, 764-75. [CrossRef]

31) Director-General for Statistics and Information Policy, Ministry of Health, Labour and Welfare, Japan Survey on Industrial Safety and Health (actual condition survey) 2016. https://www.e-stat.go.jp/stat-search/files?page=1\&layout= datalist $\&$ toukei $=00450110 \&$ tstat $=000001069310 \&$ cycle $=0$ $\&$ tclass $1=000001107395 \&$ tclass $2=000001111555 \&$ cycle facet $=$ tclass $1 \% 3$ Atclass $2 \% 3$ Acycle $\&$ second $2=1$. Accessed February 8, 2018 (in Japanese).

32) Lee K, Ashton MC. The HEXACO Personality InventoryRevised (HEXACO-PI-R). http://hexaco.org/. Accessed June 11, 2016.

33) Terwee CB, Dekker FW, Wiersinga WM, Prummel MF, Bossuyt PMM (2003) On assessing responsiveness of health-related quality of life instruments: guidelines for instrument evaluation. Qual Life Res 12, 349-62. [Medline] [CrossRef]

34) Wild D, Grove A, Martin M, Eremenco S, McElroy S, Verjee-Lorenz A, Erikson P, ISPOR Task Force for Translation and Cultural Adaptation (2005) Principles of good practice for the translation and cultural adaptation process for patient-reported outcomes (PRO) measures: report of the ISPOR task force for translation and cultural adaptation. Value Health 8, 94-104. [Medline] [CrossRef]

35) Brislin RW (1980) Translation and content analysis of oral and written material. In: Handbook of cross-cultural psychology, Triandis HC and Berry JW (Eds.), Vol. 2: Methodology, 349-444, Allyn and Bacon, Boston.

36) Morinaga Y (2012) The relationship between feedback from others and motivation. Proceedings of the Annual Meeting of Japanese Association of Administrative Science (15), 183-8 (in Japanese).

37) Ashford SJ (1986) Feedback-seeking in individual adaptation: a resource perspective. Acad Manage J 29, 465-87.

38) Morrison E (1993) Newcomer information seeking: exploring types, modes, sources, and outcomes. Acad Manage J 36, 557-89.

39) Kanai A (2000) A study on career stress - an approach to mental health from the standpoint of career development in the organization, Kazamasyobo, Tokyo (in Japanese).

40) Tanaka M (1997) A study on the factors of job satisfaction and its scale. Waseda Psychol Rep 30, 29-36 (in Japanese).

41) McLean AA (1979) Work stress, Addison-Wesley Publishing Company, Massachusetts.

42) Schaufeli WB, Bakker AB, Salanova M (2006) The measurement of work engagement with a short questionnaire: a cross-national study. Educ Psychol Meas 66, 701-16. [CrossRef]

43) Shimazu A, Schaufeli WB, Kosugi S, Suzuki A, Nashiwa H, Kato A, Sakamoto M, Irimajiri H, Amano S, Hirohata K, Goto R (2008) Work engagement in Japan: validation of the 
Japanese version of the Utrecht Work Engagement Scale. Appl Psychol 57, 510-23. [CrossRef]

44) Shimomitsu T, Haratani T, Nakamura K, Kawakami N, Hayashi T, Hiro H, Arai M, Miyazaki S, Furuki K, Otani Y, Odagiri Y (2000) Final development of the brief Job stress questionnaire mainly used for assessment of the individuals. In: The Ministry of Labour-sponsored grant for the prevention of work-related illness, FY 1999 report, Kato M (Ed.), 126-64, Ministry of Labour, Tokyo (in Japanese).

45) $\mathrm{Hu}$ Li-tze, Bentler PM (1998) Fit indices in covariance structure modeling: sensitivity to underparameterized model misspecification. Psychol Methods 3, 424-53. [CrossRef]

46) Browne MW, Cudeck R (1993) Alternative ways of assessing model fit. In: Testing structural equation models, Bollen KA and Long JS (Eds.), 136-62, Sage Publications, Newbury Park.

47) Morrison EW, Yu C, Salgado SR (2004) Cultural differences in newcomer feedback seeking: a comparison of the United States and Hong Kong. Appl Psychol 53, 1-22. [CrossRef]

48) Ashford SJ, Blatt R, Vande WD (2003) Reflections on the looking glass: a review of research on feedback-seeking behavior in organizations. J Manage 29, 773-99.

49) Ashford SJ, Tsui AS (1991) Self-regulation for managerial effectiveness: the role of active feedback seeking. Acad Manage J 34, 251-80.

50) Garst H, Frese M, Molenaar PCM (2000) The temporal factor of change in stressor-strain relationships: a growth curve model on a longitudinal study in east Germany. J Appl Psychol 85, 417-38. [Medline] [CrossRef]

51) Gabriel AS, Frantz NB, Levy PE, Hilliard AW (2014) The supervisor feedback environment is empowering, but not all the time: feedback orientation as a critical moderator. $\mathrm{J}$ Occup Organ Psychol 87, 487-506. [CrossRef]

52) Linderbaum BA, Levy PE (2010) The development and validation of the Feedback Orientation Scale (FOS). J Manage 36, 1372-405.

53) Williams JR, Miller CE, Steelman LA, Levy PE (1999)
Increasing feedback seeking in public contexts: it takes two (or more) to tango. J Appl Psychol 84, 969-76. [CrossRef]

54) Fedor DB, Eder RW, Buckley MR (1989) The contributory effects of supervisor intentions on subordinate feedback responses. Organ Behav Hum Decis Process 44, 396-414. [CrossRef]

55) Steelman LA, Rutkowski KA (2004) Moderators of employee reactions to negative feedback. J Manag Psychol 19, 6-18. [CrossRef]

56) Gouldner AW (1960) The norm of reciprocity: a preliminary statement. Am Sociol Rev 25, 161-78. [CrossRef]

57) Burke RJ, Weitzel W, Weir T (1978) Characteristics of effective employee performance review and development interviews: replication and extension. Person Psychol 31, 903-19. [CrossRef]

58) Wang M, Burlacu G, Truxillo D, James K, Yao X (2015) Age differences in feedback reactions: the roles of employee feedback orientation on social awareness and utility. J Appl Psychol 100, 1296-308. [Medline] [CrossRef]

59) Hakanen JJ, Bakker AB, Schaufeli WB (2006) Burnout and work engagement among teachers. J Sch Psychol 43, 495-513. [CrossRef]

60) Salanova M, Schaufeli WB (2008) A cross-national study of work engagement as a mediator between job resources and proactive behaviour. Int J Hum Resour Manage 19, 116-31. [CrossRef]

61) Schaufeli WB, Bakker AB, van Rhenen W (2009) How changes in job demands and resources predict burnout, work engagement, and sickness absenteeism. J Organ Behav 30, 893-917. [CrossRef]

62) Morrison EW, Vancouver JB (2000) Within-person analysis of information seeking: the effects of perceived costs and benefits. J Manage 26, 119-37.

63) Spector PE (2006) Method variance in organizational research: truth or urban legend? Organ Res Methods 9, 221-32. [CrossRef] 


\section{Appendix}

\section{職場のフィードバック環境尺度日本語版（FES-J）}

【A】 FES-J (上司)

フイードバックの情報源：上司

\section{情報源の信憑性}

上司は，私の仕事のパフォーマンスをたいていよく知っている

私は, 仕事のパフォーマンスに関する上司の意見をほぼ尊重している

仕事のパフォーマンスに対するフイードバックに関して, 私は上司をあまり信頼していない

上司は, 私の仕事のパフォーマンスを公正に評価している

私は，上司からのフィードバックを信頼している

\section{フィードバックの質}

上司は，仕事の遂行に役立つフィードバックをしている

上司からのパフォーマンスに関するフィードバックは, 役に立つ

上司からのフィードバックは有意義である

上司からのフィードバックは, 私の仕事の役に立っている

上司からのパフォーマンスに関する情報は, あまり役に立たない

\section{フィードバックの伝え方}

上司は, 仕事のパフォーマンスについてフイードバックをするとき, 私を支援するような伝え方をしてくれる

上司は, 仕事のパフォーマンスについてフィードバックをするとき, 私の気持ちを考慮してくれる たいてい上司は，あまり深く考えずにフイードバックをする

上司は, 仕事のパフォーマンスについてフイードバックをするとき, 部下をあまり大切に扱わない

上司は, 仕事のパフォーマンスについてフィードバックをするとき, 気のきいた対応をしてくれる

\section{好ましいフィードバック}

私が仕事でうまくいっているとき，上司は私のパフォーマンスをほめてくれる

上司からほめられることはめったにない

私が仕事でうまくいっているとき，上司はたいていそのことを私に伝えてくれる

私は，上司からポジティブなフィードバックを受けることが多い

\section{好ましくないフィードバック}

私が締め切りに間に合いそうにないとき，上司はそのことを指摘してくれる

私の仕事のパフォーマンスが組織の基準に達していないとき, 上司はそのことを指摘してくれる

私の仕事のパフォーマンスが期待を下回っているとき, 上司はそのことを指摘してくれる

私が仕事で間違ったことをしていると，上司はそのことを教えてくれる 


\section{情報源の対応可能性}

私が仕事のパフォーマンスについて聞きたいことがあるとき，上司はたいてい話す時間をつくってくれる

上司は忙しすぎてフィードバックをしてくれない

私は上司とほとんど交流がない

私は上司と日常的に話をしている

私が上司からパフォーマンスについてフィードバックを受けるのは，業績評価のときだけである

\section{フィードバック探索の促進}

私が直接仕事のパフォーマンスについてフィードバックを求めると, 上司は迷惑がることが多い

私が仕事のパフォーマンスについてフィードバックを求めても, 上司はすぐには応えてくれない

私は上司から, 仕事のパフォーマンスに関するフイードバックを気楽に求めることができる

上司は, 私が自分の仕事のパフォーマンスについて確信がもてないときは, いつでもフイードバックを求めるように勧める

\section{【B】 FES-J (同僚)}

フィードバックの情報源 : 同僚

\section{情報源の信憑性}

同僚は, 私の仕事のパフォーマンスをたいていよく知っている

私は, 仕事のパフォーマンスに関する同僚の意見をほぼ尊重している

仕事のパフォーマンスに対するフイードバックに関して, 私は同僚をあまり信頼していない

同僚は, 私の仕事のパフォーマンスを公正に評価している

私は, 同僚からのフィードバックを信頼している

\section{フィードバックの質}

同僚は, 仕事の遂行に役立つフィードバックをしてくれる

同僚からのパフォーマンスに関するフイードバックは, 役に立つ

同僚からのフィードバックは有意義である

同僚からのフィードバックは, 私の仕事の役に立っている

同僚からのパフォーマンスに関する情報は，あまり役に立たない

\section{フィードバックの伝え方}

同僚は, 仕事のパフォーマンスについてフィードバックをするとき, 私を支援するような伝え方をしてくれる 同僚は，仕事のパフォーマンスについてフイードバックをするとき，たいてい私の気持ちを考慮してくれる たいてい同僚は，あまり深く考えずにフイードバックをする たいてい同僚は, 仕事のパフォーマンスについてフィードバックをするとき, 人をあまり大切に扱わない 同僚は, 仕事のパフォーマンスについてフィードバックをするとき, たいてい気のきいた対応をしてくれる

\section{好ましいフィードバック}

私が仕事でうまくいっているとき，同僚は私のパフォーマンスをほめてくれる

同僚からほめられることはめったにない

私が仕事でうまくいっているとき，同僚はたいていそのことを私に伝えてくれる

私は, 同僚からポジテイブなフィードバックを受けることが多い 


\section{好ましくないフィードバック}

私が締め切りに間に合いそうにないとき，同僚はそのことを指摘してくれる

私の仕事のパフォーマンスが組織の基準に達していないとき, 同僚はそのことを指摘してくれる

私の仕事のパフォーマンスが期待を下回っているとき, 同僚はそのことを指摘してくれる

私が仕事で間違ったことをしていると, 同僚はそのことを教えてくれる

\section{情報源の対応可能性}

私が仕事のパフォーマンスについて聞きたいことがあるとき, 同僚はたいてい話す時間をつくってくれる

同僚は忙しすぎてフィードバックをしてくれない

私は同僚とほとんど交流がない

私は同僚と日常的に話をしている

\section{フィードバック探索の促進}

私が直接仕事のパフォーマンスについてフィードバックを求めると, 同僚は迷惑がることが多い

私が仕事のパフォーマンスについてフイードバックを求めても, 同僚はすぐには応えてくれない

私は同僚から, 仕事のパフォーマンスに関するフイードバックを気楽に求めることができる

同僚は, 私が自分の仕事のパフォーマンスについて確信がもてないときは, いつでもフィードバックを求めるように勧める 